\title{
Sister Chromatid Exchanges (S.C.E.) in Normal and Abnormal Bovine (Bos taurus L.) Karyotypes ${ }^{1}$
}

\author{
C. P. Popescu
}

Laboratoire de Cytogenetique, U.N.C.E.I.A.-C.N.R.Z., 78350-Jouy-en-Josas, France

Received January 11, 1977

The addition of BUDR (5-bromodeoxiuridine), a thymine analogue, to cell cultures causes various chromosomic changes, depending on the length of treatment and when the BUDR is incorporated into the DNA molecule. A short BUDR treatment of cells in the second half of the S-phase causes symmetrical chromosome segmentation (Zacharov et al. 1971), while prolonged contact over two division cycles induces sister chromatid asymmetry (Zacharov and Egolina 1968). In the first case, chromosomes may be individually recognized due to segmentation specificity (Dutrillaux 1973), while asymmetry accompanied by differential staining permits observation of sister chromatid exchanges (Latt 1973).

The replication method (Villard and Latt 1976, Nadan et al. 1976) and DNA polarity (Lin and Davidson 1974) can be equally studied by BUDR-induced asymmetry and exchange frequency serves as an indicator of the mitogenic activity of some chemical products (Allen and Latt 1976).

The pattern and frequency of chromatid exchange have been studied up to now in normal or pathological cases in man and in some laboratory species as the mouse (Lin et al. 1974, Hsu and Markvong 1975). In this report, we present the distribution and frequency of chromatid exchange in karyotypes of normal Bos taurus $\mathbf{L}$., and in a carrier of a Robertsonian-type translocation.

\section{Material and methods}

Eighteen animals were used in this study, 17 of which had a normal karyotype $(2 n=60, X Y)$ and one presented centric fusion between the largest and probably the smallest chromosome $\left(59, \mathrm{XY}, \mathrm{t}^{+}\right)$, relatively frequent in several cattle breeds (Popescu 1975).

Chromosomic preparations were made as usual according to the method of Grouchy et al. (1964) from whole blood. They were cultured 70 hours and BUDR was added to the medium at a final concentration of $200 \mu \mathrm{g} / \mathrm{ml}$ for the whole culture time.

To show exchange, we used Wolf and Perry's method (1974). The slides stained $15 \mathrm{~min}$ in a $5 \%$ solution of Hoecht Fluorochrome 33258 were mounted in water and exposed to daylight. Twenty-four hours later they were unmounted, incubated 2 hours at $65^{\circ} \mathrm{C}$ in a salt-citrate solution $(2 \times \mathrm{SSC})$ and then stained with

1 This work was partly funded by the DGRST (contract 7470803 )

2 The technical assistance of Jeannine Boscher. 


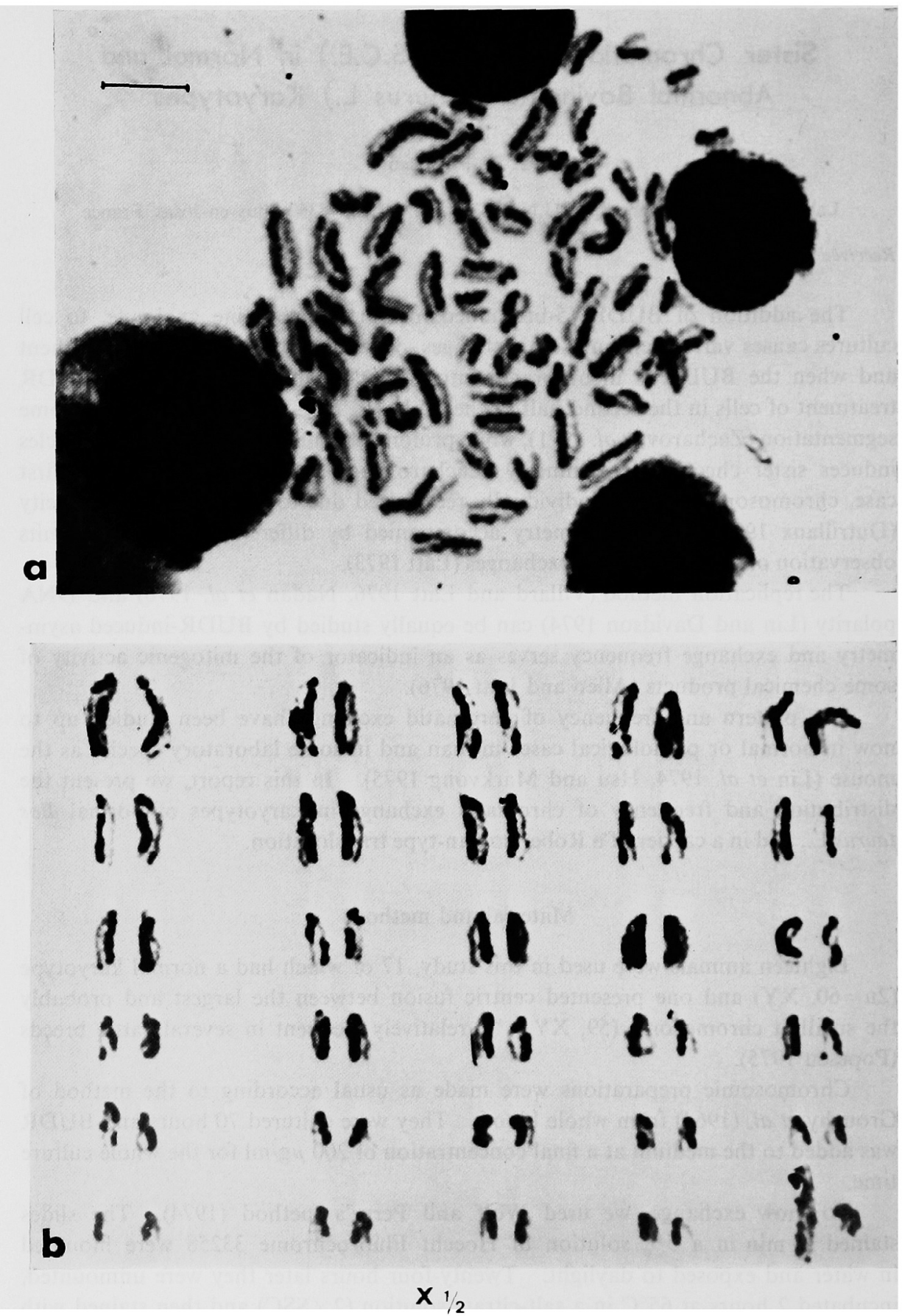

Fig. 1. Metaphase (a) and karyotype (b) of a normal cell with sister chromatid exchange. 
Giemsa. Exchanges were studied on the photos taken with a Leitz Ortholux microscope in normal daylight.

\section{Results}

After two cell cycles in presence of BUDR, the chromosomes present a very dark chromatid, intensely stained with Giemsa, and another slightly longer and weakly stained (Figs. 1a and b). The first, appearing under fluorescence after intense acridine green staining (Dutrillaux et al. 1974), incorporated the BUDR in a single DNA strand (T-B). The other chromatid, weakly stained with Giemsa and pale green under fluorescence, fixed BUDR on the two DNA strands (B-B).

Table 1. Chromatid exchange frequency in normal cattle karyotypes and in the carrier of $1 / 29$ centric fusion

\begin{tabular}{lccccccc} 
Karyotype & $\begin{array}{c}\text { No. of } \\
\text { cells } \\
\text { studied }\end{array}$ & $\begin{array}{c}\text { No. of } \\
\text { chromo- } \\
\text { somes } \\
\text { studied }\end{array}$ & $\begin{array}{c}\text { Total } \\
\text { no. of } \\
\text { exchanges }\end{array}$ & $\begin{array}{c}\text { Exchange } \\
\text { mean } \\
\text { per } \\
\text { cell }\end{array}$ & $\begin{array}{c}\text { Exchange } \\
\text { mean } \\
\text { per } \\
\text { chromo- } \\
\text { some }\end{array}$ & $\begin{array}{c}\text { Exchanges } \\
\text { between } \\
\text { homolo- } \\
\text { gous } \\
\text { chromo- } \\
\text { somes }\end{array}$ & $\begin{array}{c}\text { Quadriradial } \\
\text { formation }\end{array}$ \\
\hline Normal & 52 & 2974 & 602 & 10.37 & 0.202 & 7 & 1 \\
Aberrant & 8 & 452 & 130 & 16.26 & 0.287 & - & -1 \\
Total & 60 & 3426 & 732 & 12.2 & 0.213 & 7 & 1 \\
\hline
\end{tabular}

From all the cells studied we recorded a total of 732 sister chromatid exchanges, or a mean of 12.2 exchanges per cell (Table 1). The mean number of exchanges per chromosome, depending on the number of exchanges per cell, is 0.21 .

An analysis of variance done on 11 normal animals to compare their mean number of exchanges per cell shows a significant difference between individuals at the $0.5 \%$ threshold $(F=3.41$ for 10 and $35 \mathrm{DF})$.

Bos taurus autosomes are all acrocentric and thus difficult to identify. However, there are more exchanges on large-sized chromosomes.

The localization of chromosome exchange is very variable because it occurs all along the chromatid. The exchanges observed are found in various sites along the chromosome; slightly more are seen in the telomeric regions.

Exchanges between homologous chromosomes are rarer; we only saw 7 on all the chromosomes studied (Figs. 2b, $\mathrm{c}$ and d,). A quadriradial formation (Fig. 2a) was identified in one animal presenting more than four exchanges between homologous chromosomes on eight cells studied.

The animal carrying $1 / 29$ centric fusion had a mean number of 16 ( 26 exchanges per cell), comparable to those of some normal animals. On the fused chromosome, we observed from 0 to 4 exchanges on various cells, generally located on the long arm corresponding to the largest chromosome of the complement (Figs. 3a-d).

\section{Discussion}

The differential staining of chromosomes after two cell cycles in presence of BUDR has not yet been satisfactorily explained. Latt (1973) thinks the fluorescence 


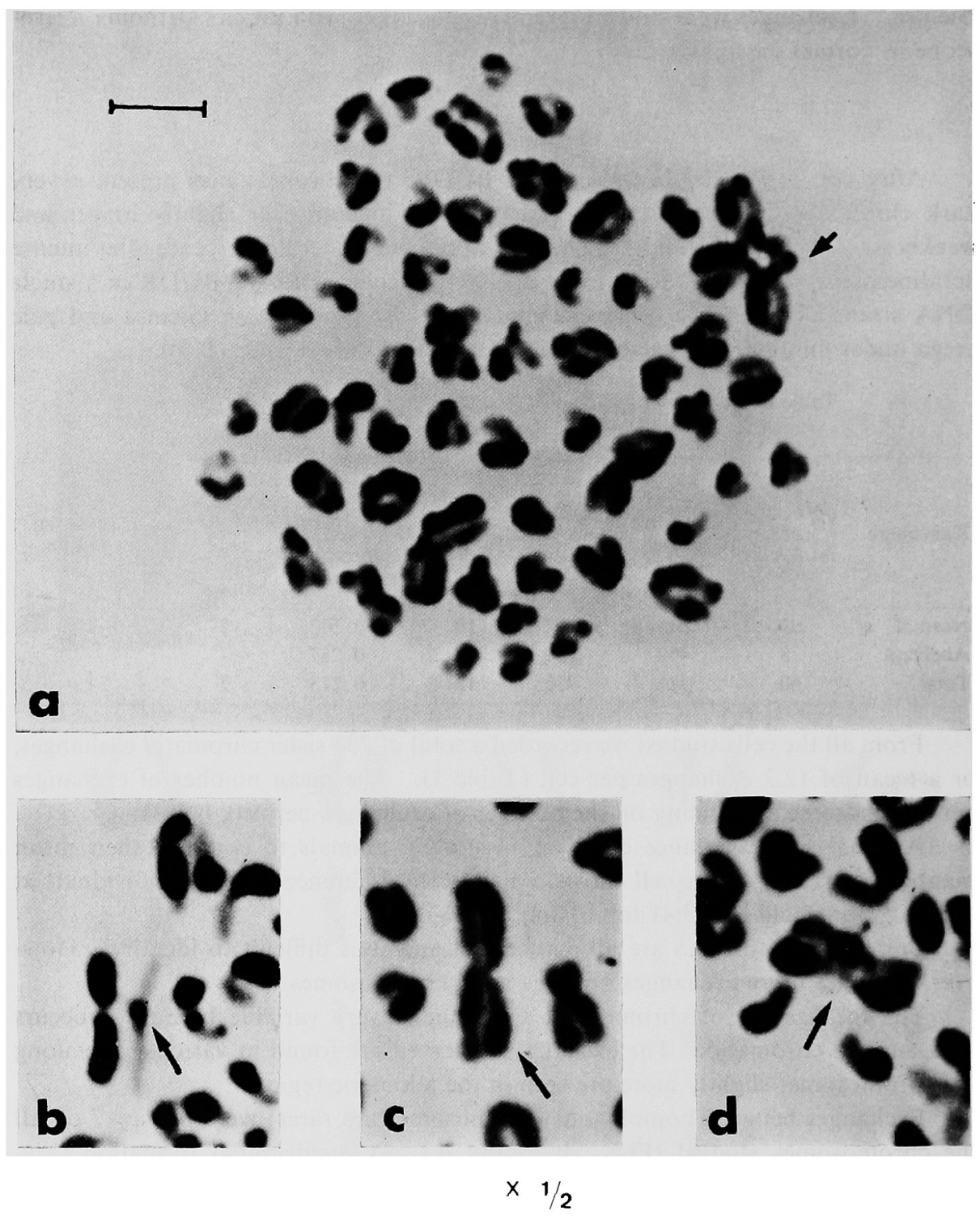

Fig. 2. a, quadriradial formation (shown by arrow) in a normal cell. b, c and d, homologous chromosome exchange from 3 different cells.

of Hoechst fluorochrome 33258 decreases $20 \%$ when bound to DNA in which BUDR is substituted for thymine. However, this cannot explain the reduced affinity of this same B-B chromatid for Giesma. Thus, Goto et al. (1975) and Sugiyama et al. (1976) believe it is due to rapid DNA photolysis in the B-B chromatid; its mechanism, however, is unknown.

Sister chromatid exchange was seen for the first time by Taylor et al. (1957) using autoradiography after tritiated thymidine incorporation. Based on sub. 


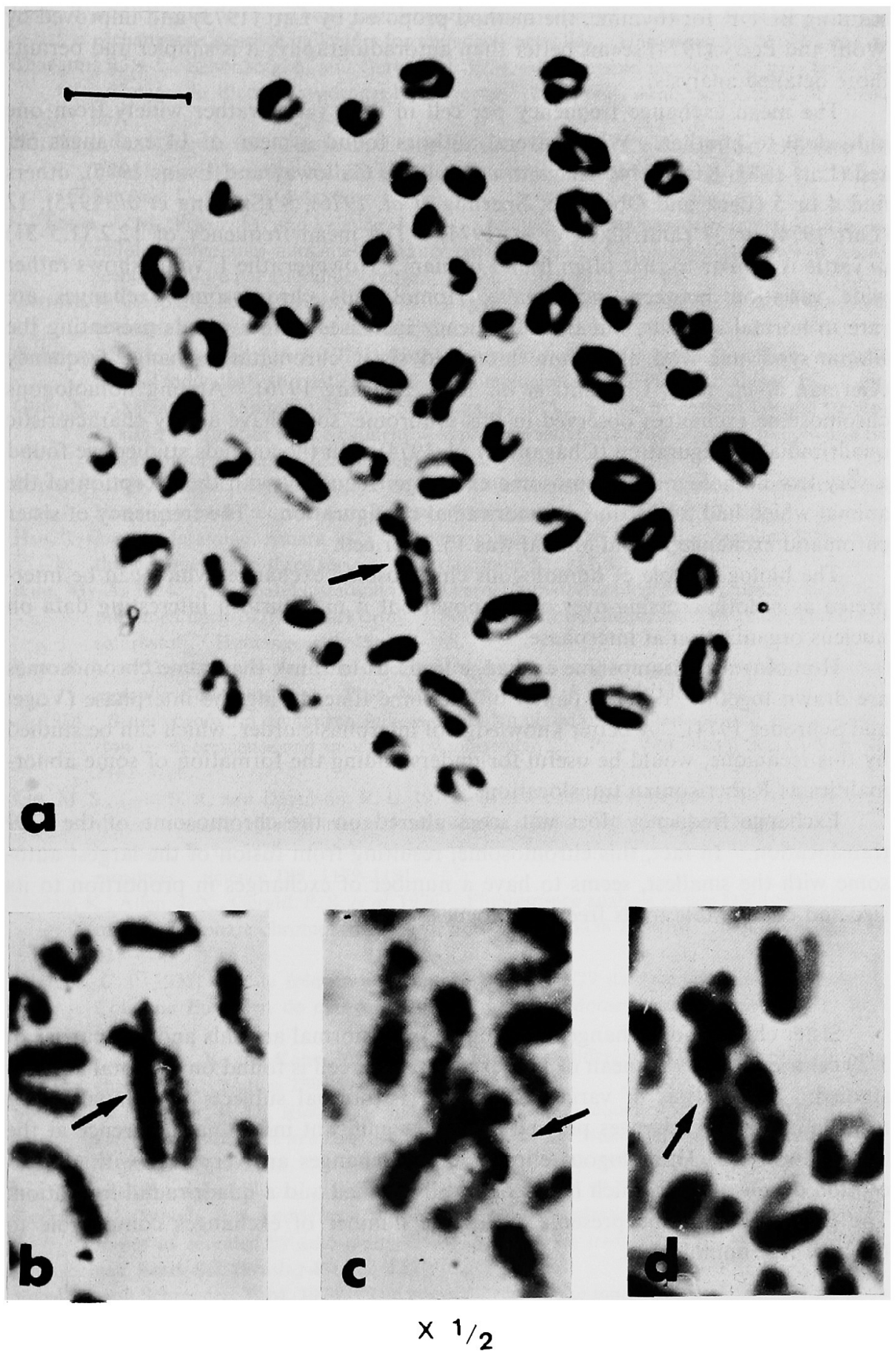

Fig. 3. a, metaphase carrying $1 / 29$ centric fusion. Abnormal chromosome is shown by arrow. $\mathrm{b}, \mathrm{c}$ and $\mathrm{d}$, abnormal chromosome in 3 different cells. 
stituting BUDR for thymine, the method proposed by Latt (1973) and improved by Wolff and Perry (1974) seems better than autoradiography; it is simpler and permits more detailed analysis.

The mean exchange frequency per cell in man varies rather widely from one individual to another. While several authors found a mean of 14 exchanges per cell (Latt 1973, Kim 1974, Chaganti et al. 1974, Galloway and Evans 1975), others find 4 or 5 (Beek and Obe 1975, Sperling et al. 1976), 8 (Sperling et al. 1975), 12 (Latt 1974) or 27 (Dutrillaux et al. 1974). The mean frequency of 12.2 (1.5-31) in cattle is similar to that often found in man. However, the $F$ value shows rather wide variation between individuals. Homologous chromosome exchanges are rare in normal subjects, but their frequency increases in individuals presenting the Bloom syndrome who also show increased sister chromatid exchange frequency (German et al. 1974, Chaganti et al. 1974, Sperling 1976). Among homologous chromosome exchanges observed in this syndrome, some have a very characteristic quadriradial configuration (Chaganti et al. 1974). In the animals studied we found a very low homologous chromosome exchange frequency with the exception of the animal which had 5 and thus a quadriradial configuration. The frequency of sister chromatid exchange in that animal was 15.2 per cell.

The biological role of homologous chromosome exchange, which can be interpreted as mitotic crossing-over, is unknown but it may furnish interesting data on nucleus organization at interphase.

Homologous chromosome exchange leads us to think that some chromosomes are drawn together, or even paired off, at some time during the interphase (Vogel and Schroder 1974). A better knowledge of interphasic order, which can be studied by this technique, would be useful for understanding the formation of some abnormalities as Robertsonian translocations.

Exchange frequency does not seem altered on the chromosome of the $1 / 29$ translocation. In fact, this chromosome, resulting from fusion of the largest autosome with the smallest, seems to have a number of exchanges in proportion to its size and comparable to its free homologues.

\section{Summary}

Sister chromatid exchanges are studied in 17 normal animals and one carrier of $1 / 29$ centric fusion. A mean of 12.2 exchanges per cell is found on the total animals studied. An analysis of variance done on 11 normal subjects to compare their mean number of exchanges per cell shows a significant individual difference at the $0.5 \%$ threshold. Homologous chromosome exchanges are very rare with the exception of one animal which had 4 on 8 cells studied and a quadriradial formation: The fused chromosome presents a variable number of exchanges comparable to those of free homologues.

\section{References bibliographiques}

Allen, $\mathbf{y}$. W. and Latt, S. A. 1976. Analysis of sister chromatid exchange formation in vivo in mouse spermatogonia as a new test system for environmental mutagens Nature 260: 449-451. 
Beek, B, and Obe, G. 1975. The human leucocyte test system VI. The use of sister chromatid exchanges as possible indicators for mutagenic activities. Humangenetik 29: 127-134.

Chaganti, R. S. L., Schonberg, S. and German, J. 1974. A manyfold increase in sister chromatid exchnages in Bloom's syndrome lymphocytes. Proc. Nat. Acad. Sci. U.S.A. 71: 45084512.

Dutrillaux, B., Laurent, C., Couturier, J. and Lejeune, J. 1973. Coloration des chromosomes humains par l'acridine orange, après traitement par le 5 bromodéoxyuridine C. $r$. Acad. Sci. Ser; D. 276: 3719-3182.

-, Fosse, A. M., Prieur, M. and Lejeune, J. 1974. Analyse des échanges de chromatides dans les cellules somatiques humaines. Traitement au BUDR ( 5 bromodéoxyuridine) et fluorescence bicolore par l'acridine orange. Chromosoma 48: 327-340.

German, J., Crippa. L, P. and Bloom, D. 1974. Bloom syndrome III. Analysis of the chromosome aberration characteristic of this disorder. Chromosoma 38:361-366.

Galloway, S. M. and Evans, H. J. 1975. Sister chromatid exchange in human chromosomes from normal individuals and patients with ataxia talangiectasia. Cytogenet. Genet. 15: 17-29.

Goto, K., Akematsu, T., Shimazu, H., and Sugiyama, T. 1975. Simple differential Giemsa staining of sister chromatids after treatment with photosensitive dyes and exposure to light and the mecanism of staining. Chromosoma 53: 223-230.

Grouchy, J. de, Roubin, M. and Passage, E. 1964. Microtechnique pour l'étude des chromosomes humains à partir d'une culture de leucocytes sanguins. Ann. Génét. 7: 45.

Hsu, T. C. and Markvong, Amara 1975. Chromosomes and DNA of Mus: terminal DNA Synthetic sequences in three species. Chromosoma 51: 311-322.

Kim, My A. 1974. Chromatidaustausch und Heterochromatinveränderungen menschlicher Chromosomen nach BUDR-Markierung. Nachweis mit Benzimidazolfluorochrom und Giemsafarbstoff. Humangenetik 25: 179-188.

Latt, S. A. 1973. Microfluorometric detection of deoxyribonucleic acid replication in human metaphase chromosomes. Proc. Nat. Acad. Sci. U. S. A. 70: 3395-3399.

- 1974. Sister chromatid exchanges, indices of human chromosome damage and repair: detection by fluorescence and indication by mitomycin C. Proc. Nat. Acad. Sci. U. S. A. 71 : 3162-3166.

Lin, M. S., Latt, S. A. and Davidson, R. L. 1976. Microfluorometric detection of asymmetry in the centromeric region of mouse chromosomes. Exptl. Cell. Res. 86: 392-395.

- and Davidson, R. L. 1976. Centric fusion, satellite DNA and DNA polarity in mouse chromosomes. Science 185: 1179-1181.

Nadan, K., Allen, J. X., Gerald, P. S. et al. 1976. Fluorescence analysis of late DNA replication in mouse metaphase chromosomes using BUDR and 33258 Hoechst. Exp. Cell. Res. 99 : 438-444.

Popescu, C. P. 1975. Sur la fréquence de la translocation 1/29 dans certaines races bovines II. Colloque Européen de cytogénétique des animaux domestiques. Giessen 29-30 Sept. $277-282$.

Sugiyama, T., Goto, K. and Kano, Y. 1976. Mechanism of differential Giemsa method for sister chromatids. Nature 259: 59-60.

Sperling, K., Wegner, R. D., Riehm, H. and Obe, G. 1975. Frequency and distribution of sister chromatin exchanges in a case of Franconi's anemia. Humangenetik 27: 227-230.

-, Goll, V., Kunze, Z., Ludtke, E. K., Tolksdorf, M. and Obe, G. 1976. Cytogenetic investigations in a new case of Bloom's syndrome. Hum. Genet. $31: 47-52$.

Taylor, J. H., Woods, P. S. and Huges, W. L. 1957. The organization and duplication of chromosomes as revealed by auto-radiographic studies using tritium labelled thymidine. Proc. nat. Acad. Sci. (Wash.) 43: 122-127.

Vogel, F, and Schroeder, T. M. 1974. The internal order of the interphase nucleus. Humangenetik 25: 265-298.

Willard, H. F. and Latt, S. A. 0000 Analysis of deoxyribonucleic acid replication in human X chromosomes by fluorescence microscopy. Amf. J. Human Genet. 28: 213-227.

Wolff, S. and Perry, P. 1974. Differential Giemsa staining of sister chromatide and the study of 
sister chromatid exchanges without atuoradiography. Chromosoma 48: 341-353.

Zakharov, A. F. and Egolina, N. A. 1968. Asynchrony of INA replication and mitotic spiralization along heterochromatic portions of Chinese hamster chromosomes. Chromosoma 23: $365-385$.

-, Seleznev, Y. V., Benjuch, V. A., Baranovskaya, L. I. and Demintseva, V. S. 1971. Differentiation along human chromosomes in relation to chromosome identification. In 4th Int. Congr. of Human Genet. Exupta Medica. Amsterdam. Int. Cong. Ser. 233: 193. 